
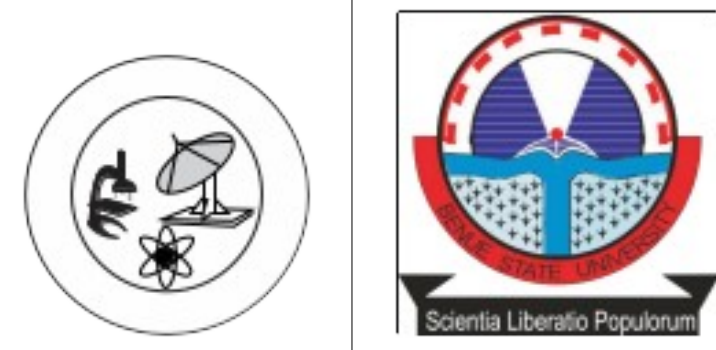

\title{
Lipid Profile of Streptozotocin-Induced Diabetic Wistar Albino Rats Treated with Aqueous Extracts of Nauclea latifolia
}

\author{
Ochalefu D.O' ${ }^{1}$, Adoga G.I', Luka C.D², Abu H.A ${ }^{3}$ and \\ Olaniru O. B ${ }^{4}$ \\ Department of Medical Biochemistry, College of Health Sciences, \\ Benue State University, Makurdi, Nigeria. ${ }^{1}$
}

Department of Biochemistry, Faculty of Medical Sciences, University of Jos, Jos, Plateau State, Nigeria. ${ }^{2}$

Department of Veterinary Physiology, Pharmacology and Biochemistry, College of Veterinary Medicine, University of Agriculture, Makurdi, Nigeria. ${ }^{3}$

Department of Chemical Pathology, Jos University Teaching Hospital, Jos, Plateau State, Nigeria. ${ }^{4}$

Correspondence Author: dickochalefu@gmail.com.

\begin{abstract}
In recent times there has been a steady increase in researches aimed at searching for plant agents that can be used in the management of diabetes mellitus and its complications with minimal side effects compared with the anti-diabetic drugs in the pharmaceutical market. This work is on the effect of aqueous extracts of Nauclea latifolia plant on serum lipid profile in streptozotocin- induced diabetic rats. Thirty mature male Wistar albino rats were divided into six treatment groups of five rats each. Group A was normal control and group B was streptozotocin-induced diabetic control. Groups C, D and E were streptozotocin- induced diabetic rats treated daily with $500 \mathrm{mg} / \mathrm{kg}$. body weight of aqueous extracts of stem-bark, leaves and root-bark of Nauclea latifolia respectively. Group F was streptozotocin- induced diabetic rats treated daily with $5 \mathrm{mg} / \mathrm{kg}$. body weight of glibenclamide and the treatment was for 28 days. The serum total cholesterol, high density lipoprotein cholesterol and triacylglycerol of the rats were determined using assay kits from Agape Diagnostic, Switzerland while very low density lipoprotein cholesterol was determined by calculation according to the method of Burstein and Samaile (1960). The low density lipoprotein cholesterol was estimated using the method of Friedwald, Levy and Fredrickson (1972) which entails differential subtraction of the sum of the cholesterol fractions from the total cholesterol. The parameters were analyzed using One- way Analysis of Variance with the level of significance determined by least significant difference. The streptozotocin-induced diabetic control rats had their serum levels of total cholesterol, low density lipoprotein cholesterol, very low density lipoprotein cholesterol and triacylglycerol significantly elevated compared with the normal control. Nauclea latifolia aqueous extracts brought about significant reduction of total cholesterol, low density lipoprotein cholesterol and triacylglycerol levels in the diabetic treated rats. The outcome of this work indicates that Nauclea latifolia aqueous extracts have ameliorating effect on diabetic complications due to high serum lipid profile levels.
\end{abstract}

Keywords:Nauclea latifolia, Lipid profile, Streptozotocin, Extracts 


\section{Introduction}

Diabetic mellitus is a chronic metabolic disease that affects about $10 \%$ of the global population. It is a disorder of the endocrine system which is characterized by abnormalities in carbohydrate, protein and fat metabolism resulting from complete or relative insufficiency of insulin secretion and action (Effiong and Essien, 2017). Diabetes mellitus has become an important public health concern especially in the developing countries (Asangaet al., 2013). People with untreated diabetes mellitus generally end up having lipoprotein abnormalities because it is a metabolic ailment that is accompanied with impaired glucose metabolism which leads to dyslipidaemia (Owolabi and Omogbai, 2011).

It is commonly known that patients with diabetes mellitus mostly have elevated triacylglycerol, total cholesterol and low density lipoprotein cholesterol concentration while the concentration of high density lipoprotein cholesterol level is decreased (Omonkhelinet al., 2011). Abnormal high levels of these lipids in the blood result in a buildup of fatty deposits in the inner walls of the arteries that feed the heart and the brain and together with other substances form plague that narrows the arteries (Law, 1999; Owolabi and Omogbai, 2013). Changes in plasma lipid and lipoprotein profile are regarded as risk factors for coronary heart disease (Rekha, Balaji and Deecaraman, 2010; Betterridge, 2002). Dyslipidaemia which ranges from hypercholesterolaemia to hypocholesterolaemia is one of the many modifiable risk factors for coronary artery disease, stroke and peripheral vascular disease (Dasofunjoet al., 2013).

Many synthetic drugs have been made for the management of diabetes mellitus but these drugs have their short comings in terms of their efficacy and adverse effects. In view of this, there is much interest in the discovery of natural products that can be beneficial in the disease management with very minimal side effects while reducing the risk factors associated with diabetes mellitus. There has been search for appropriate medicinal plants' agents against atherosclerosis and other cardiovascular related disorders secondary to lipid abnormalities in diabetes mellitus (Rang et al., 2003; Thomson et al., 2007; Dasofunjoet al., 2013).

The extracts of Nauclealatifolia plant (African peach) called Oya among the Idoma natives of Benue State, Nigeria, Tafashiya among the Hausas of Northern Nigeria and Ubuluinuin Ibo land of Eastern Nigeria have been reported to possess hypoglycaemic property and preliminary phytochemical screening showed that it contains alkaloids, saponins, tannins, reducing sugar, phlobatanins, anthraquinones and flavonoids (Ochalefuet al., 2018). Nauclealatifolia is an evergreen multi-stemmed shrub or tree. It grows up to a height of between 10 - 30 metres. Its natural habitat is the humid tropical rain forest zone or the savannah wood lands of West Africa and Central Africa (Okworiet al., 2008).

This research was designed to evaluate the effects of aqueous extracts of Nauclealatifolia on blood lipid profile which includes Total cholesterol, High density lipoprotein cholesterol, Triacylglycerol, Low density lipoprotein cholesterol and Very low density lipoprotein cholesterol.

\section{Materials and Methods}

\section{Collection and Identification of Plant Material}

The plant material was harvested from the environs of the Federal University of Agriculture, Makurdi, Benue State, Nigeria. The plant was identified and authenticated by Mr. J .J. Azila of the Federal School of Forestry, Jos, Plateau State, Nigeria where a voucher number FHJ 279 was assigned. Samples of the plant were deposited at the school's herbarium.

\section{Preparation of Extracts}

The leaves, stem-bark and root-bark were air-dried at room temperature, pulverized using pestle and mortar and then stored in air-tight containers until the time of use. One hundred grammes $(100 \mathrm{~g})$ of the leaves, stem -bark and root-bark powder was separately weighed using an electronic 
weighing machine (Mettlertoledo). The leaves, stem-bark and root-bark powder were separately soaked in $1000 \mathrm{ml}$ of distilled water at a ratio of 1:10 (powder/solvent) (Das, Tiwari \&Shrivastava, 2010). These were stirred intermittently for 48 hours at room temperature. The soaked powder was filtered using muscilin cloth after which sterile cotton wool and Whatman filter paper No1 size $110 \mathrm{~mm}$ were used to obtain a pure filtrate. The filtrates were then separately concentrated to dryness using water bath at temperature of $45^{\circ} \mathrm{C}$ yielding $13.30 \mathrm{~g}(13.3 \%), 11.09 \mathrm{~g}(11.09 \%)$ and $15.02 \mathrm{~g}$ $(15.02 \%)$ for leaves, root-bark and stem-bark respectively. The extracts were then stored in the refrigerator at $4^{\circ} \mathrm{C}$ from where aliquots were used for the study.

The percentage yield was calculated by the expression:

$$
\% \text { yield }=\frac{\text { Weight of extract }(\mathrm{g})}{\text { Weight of dried sample }(\mathrm{g})} \times 100
$$

\section{Research Design \\ Animal studies}

White albino rats of wistar strain used for the study were obtained from the Animal House, College of Health Sciences, Benue State University, Makurdi, Nigeria. They were kept in polypropylene cages under room temperature, with 12-hour light and 12-hour dark cycle. They were allowed to acclimatize for two weeks before the commencement of the experiment. The rats were divided into six groups of five rats each. Group A was normal control and group B was streptozotocin-induced diabetic control. The controls were administered $1 \mathrm{ml}$ distilled water orally. Groups C, D and E were streptozotocin induced diabetic rats treated with $500 \mathrm{mg} / \mathrm{Kg}$. body weight of stem-bark, leaves and root-bark extracts of Nauclealatifolia respectively for 28 days and group F was streptozotocin- induced diabetic rats given $5 \mathrm{mg} / \mathrm{kg}$. body weight of the standard anti-diabetic drug, Glibenclamide by Sanofi-Aventis, Nigeria Limited, daily for 28 days (Effionget al., 2013). The extracts and glibenclamide were administered orally through intra-pharyngeal feeding canula. The rats were fed ad libitum with pellet diet (Grand Cereals Ltd, Jos, Nigeria) and clean tap water. Good hygiene was maintained by constant cleaning and removal of faeces and spills from cages daily. The experiment was conducted between the hours of 9.00A.M and 11.00 A.M. The protocols for these experiments were in accordance with the ethical guidelines on the care and use of laboratory animals (NIH, 1985).

\section{Acute Oral Toxicity}

The acute oral toxicity study was conducted using limit dose test of revised Up-and-Down procedure (OECD, 2001). Five female rats one at a time were administered $5000 \mathrm{mg} / \mathrm{Kg}$. body weight of Nauclealatifolia extracts (separate administration for the leaves, stem- bark and root-bark extracts) after overnight fast of food.

Each rat was observed each time for the first 5 minutes after dosing for signs of regurgitation and then kept in the cage and then watched for every 15 minutes in the first 4 hours after dosing then every 30 minutes for the successive 6 hours. Thereafter, observations were made daily for 14 days in case of delayed toxicity.

\section{Induction of Diabetes Mellitus}

Diabetes mellitus was induced in overnight fasted rats weighing between 153.5-177.0 grammes by single intra-peritoneal injection of freshly prepared streptozotocin (Sigma-Aldrich, Germany) $60 \mathrm{mg} / \mathrm{kg}$ body weight in $0.1 \mathrm{M}$ citrate buffer ( $\mathrm{pH} 4.5$ ) (Adoga and Ibrahim, 1990; Ghoraishian, 2006; Rao and Naibu, 2010). Diabetes was confirmed in the Streptozotocin treated rats by measuring fasting blood glucose concentration using Glucometer (Accu-Chek, Mannheim, Germany) 48 hours after streptozotocin injection. Rats with fasting blood glucose of more than $200 \mathrm{mg} / \mathrm{dl}$ were considered diabetic and included in the study.

\section{The Determination of Lipid Profile}


The assay kits for the determination of Total Cholesterol (TC), High Density Lipoprotein Cholesterol (HDL-C) and Triacylglycerol were obtained from Agape Diagnostic Switzerland. Very Low Density Lipoprotein Cholesterol (VLDL-C) was determined by calculation according to the method of Burstein and Samaile (1960). The serum Triacylglycerol concentration was divided by a factor of 5. This factor was based on the understanding that in fasting human subjects with Triacylglycerol concentration of $400 \mathrm{mg} / \mathrm{dl}$, the Very Low Density Lipoprotein to Total Cholesterol ratio is relatively fixed at 1: 5. The Low Density Lipoprotein Cholesterol (LDL-C) was estimated using the method of Friedwald, Levy and Fredrickson (1972) which entails differential subtraction of the sum of the cholesterol fractions from the total cholesterol. That is: LDL= TC- HDL-VLDL

\section{Statistical Analysis}

Statistical analysis was done using the statistical package for social sciences (SPSS). The results were expressed as Mean \pm SEM (standard error of mean), where $n=5$, analyzed by one-way Analysis of Variance (ANOVA) and the level of significance determined by least significant difference (LSD). The $\mathrm{p}$ values of 0.05 and less were taken to imply statistical significance between the means.

\section{Results \\ Results of Acute Toxicity Studies}

The acute oral toxicity studies done using the aqueous extracts of Nauclealatifolia leaves, stem-bark and root-bark revealed no mortality in the rats when $5000 \mathrm{mg} / \mathrm{kg}$ body weight of extracts were administered respectively within the short and long term outcome of the limit dose of the Upand- Down procedure. The aqueous extracts had no side effects on the nervous system evidenced by lack of convulsion of the rats. Adverse changes in breathing and behavior were not noticed. Abnormal changes in stooling and urination habits were not observed within the toxicity study period.

\section{Results of Lipid Profile}

Table 1 shows the results of the lipid profile. The results show that diabetes mellitus induced by intra-peritoneal injection of streptozotocin increased significantly $(\mathrm{p}<0.05)$ serum levels of total cholesterol, triacylglycerol, low density lipoprotein cholesterol and very low density lipoprotein cholesterol in the rats. Serum high density lipoprotein cholesterol level was significantly reduced (p $<0.05)$ by the streptozotocin injection. The results revealed significant decrease $(p<0.05)$ in serum levels of total cholesterol, low density lipoprotein cholesterol and triacylglycerol in the extracts treated rats. There was non- significant increase $(p>0.05)$ in the serum level of high density lipoprotein cholesterol by the leaves and root-bark aqueous extracts of Nauclealatifolia (Table 1).

\section{Discussion}

That no mortality of the rats was observed using limit dose of $5000 \mathrm{mg} / \mathrm{kg}$. body weight of aqueous extracts of Nauclealatifolia in the acute toxicity studies implies that the aqueous extracts used have low toxicity when administered orally. This finding agrees with earlier reports of Assam, Dzoyen, Pieme and Penlap (2010) who administered Nauclealatifoliaethanolic extract to mice at $8000 \mathrm{mg} / \mathrm{kg}$. body weight and found no major signs of clinical toxicity within the period of toxicity studies.

The significant rise in serum total cholesterol, triacylglycerol, low density lipoprotein cholesterol in the streptozotocin-induced diabetic control rats compared with the normal control observed in this study is in consonance with the findings of the research work by Bakoet al (2014) who found significant rise $(\mathrm{p}<0.05)$ in these lipid profile parameters in diabetic rats. This significant increased serum lipid profile seen in the streptozotocin-induced diabetic control rats may be due to disturbances in the regulation of the activity of lipase, the hormone- sensitive enzyme, by insulin due to its absence or insufficiency resulting from streptozotocin-induced damage to the beta cells of the islets of Langerhans of the pancreas. 
Table 1:Effects of Aqueous Extracts of Stem-bark, Leaves and Root-bark ofNauclealatifolia on Lipid Profile in Streptozotocin induced Diabetic Wistar Albino Rats

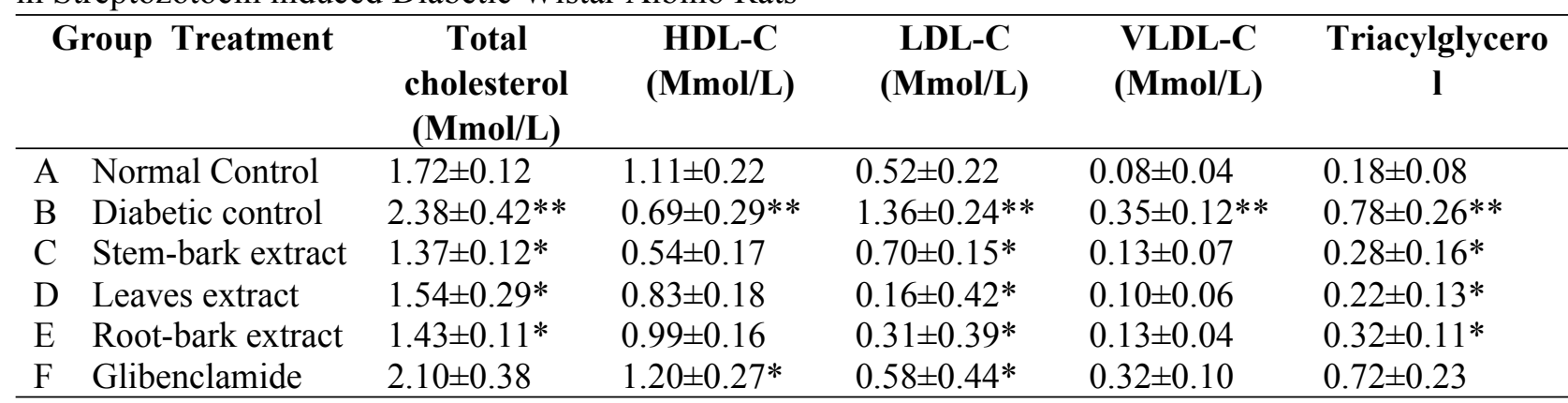

$\overline{H D L}-\mathrm{C}=$ High density lipoprotein cholesterol; $L D L-C=$ Low density lipoprotein cholesterol; $V L D L-C=V e r y$ low density lipoprotein cholesterol; Values are Mean \pm SEM of 5 determinations; * = Statistically significant when compared to diabetic control at $(p<0.05)$ and $* *=$ Statistically significant when compared to normal control at $\quad(p<0.05)$

It is known that lipase enzyme converts triacylglycerol to free fatty acids and glycerol. Insulin inhibits lipase in adipose tissue. The absence of insulin, therefore, leads to increased plasma level of free fatty acids due to unopposed action of lipase. In the liver hepatocytes, the free fatty acids are catabolised to acetyl coenzyme A that is subsequently converted to cholesterol and triacylglycerol when produced in excess due to the metabolic derangement (Pari and Latha, 2005; Al-Shamaonyet al., 1994). The abnormally high level of serum lipoprotein in the diabetic control rats may also be attributed to the mobilization of free fatty acids from the peripheral fat depots by glucagon in the absence of insulin (Bakoet al., 2014). The excess of fatty acids in serum resulting from the streptozotocininduced diabetes mellitus enhances the liver's conversion of fatty acids into triacylglycerol, phospholipids and cholesterol which may be discharged into the blood stream as lipoproteins (Bopannaet al., 1997; Bakoet al., 2014; Pari and Latha, 2005).

The significant reduction $(\mathrm{p}<0.05)$ by the Nauclealatifolia aqueous extracts in the lipid profile in the diabetic treated rats in this study agrees with the research findings of Omonkhelinet al (2014) in which they found that the use of extracts of Napoleonavogeliiondiabetic rats significantly lowered the high levels of total cholesterol, triacylglycerol, low density lipoprotein cholesterol and very low density lipoprotein cholesterol in the diabetic rats. The findings in this study also concurs with the work of Ahmad et al (2010) who used the extract of Peucedanumpastinacifoliumon streptozotocininduced diabetic rats with high lipid profile but found out that the total cholesterol, low density lipoprotein cholesterol and triacylglycerol were significantly decreased $(p<0.05)$ following treatment with the plant extract.

The significant decrease $(p<0.05)$ of the lipid profile shown by the aqueous extracts of Nauclealatifolia might be as a result of the extracts causing regeneration of the $\beta$-cells of the islets of Langerhans of the pancreas and potentiation of insulin secretion from the surviving $\beta$ - cells. The rise in insulin secretion with resultant reduction in blood glucose level may cause stimulation of fatty acids biosynthesis and also the incorporation of fatty acids into triacylglycerols in the liver and adipose tissue. The presence of insulin inhibits the action of lipase in the adipose tissue. The activity of glucagon in the adipose tissue is also inhibited. This explains the decreased plasma level of free fatty acids thereby leading to relatively low lipid profile (Best and Taylor, 1989; Bakoet al., 2014). The plasma levels of very low density lipoprotein and low density lipoprotein will decrease since there is no elevated level of fatty acids from lipolysis and from breakdown of triacylglycerol by the hormone sensitive lipase that will be converted to acetyl coenzyme A which are precursors of cholesterol, 
triacylglycerol and phospholipids. The major lipids carried by lipoprotein are triacylglycerol and cholesterol. When the levels of cholesterol and triacylglycerol in the liver are not increased, there will be decreased synthesis of lipoprotein (Bopannaet al., 1997).

\section{Conclusion}

The results of this study have shown that aqueous extracts of Nauclealatifolia plant possess anti-hyperlipidaemic activity in diabetic rats. This implies that it has beneficial effect in the management of diabetic complications like atherosclerosis and coronary heart disease caused by hyperlipidaemia.

\section{References}

Adoga, G. I., and Ibrahim, M. B. (1990). Effect of garlic oil on some biochemical parameters in streptozotocin-induced diabetic rats. Medical Science Research, 18:859-860.

Ahmad, B. Z., Ebrahim, S., and Reza, M. (2010). Anti-hyperglycaemic effect of Pencedanumpastinacifolium extract in streptozotocin-induced diabetic rats. Clinics, 65 (6): 629-633.

Al -Shamaony, L., Al- Khazraji, M.S., and Twaij, H. A. (1994). Hypoglycaemic effects of Artemisia herba-alba II. Effect of valuable extract on some blood parameters in diabetic animals. $J$. Ethnopharmacol., 43 (3): 167-171.

Asanga, E., Patrick, E., Olorunfemi, E., Imaobong, U., Robert, E., and Effiong, G. (2013). Lipid profile of alloxan-induced diabetic albino wistar rats treated with ethanol whole extract and fractions of Nauclealatifolia leaves. ARPN Journal of Science and Technology, 3 (10): 10091012.

Assan, J.P., Dzoyen, C. A., Pieme, V.B., and Penlap, P. (2010). In-vitro anti-bacterial activity and acute toxicity studies of aqueous methanol extract of Sidarhomifolialinn. BMC Complementary and Alternative Medicine, 10, 40.
Bako, Y. H., Mohammed, S.T., Waziri, M. P., Bulus, T., Gwarzo, Y. M., and Zubairu, M.M. (2014). Lipid profile of alloxaninduced diabetic wistar rats treated with methanolic extract of Adansoniadigitata fruit pulp. Science World Journal (2). www.scienceworldjournal.org.

Betterridge, J. (2002). Lipid disorders in diabetic mellitus. In Pickup $\mathrm{J}$ and Williams $\mathrm{G}$ (eds). Textbook of diabetes. Blackwell Science: London

Best, C. H., and Taylor, N.B. (1989). Biologial effects of insulin. In :Physiologial Basis of Medical Practice, Wilkins, W.W (Ed.) Cambridge University Press: London.

Bopanna, K. N., Kannan, J., Sushma, G., Balaraman, R., and Rathod, S.P. (1997). Anti-diabetic and anti-hyperlipidaemic effects of neem seed kernel powder on alloxan diabetic rabbits. Indian Journal Pharmacol. 29: 162-167.

Burstein, M., and Samaile, J., (1960). On rapid determination of the cholesterol bound to the serum alpha- and beta-lipoproteins. Clinical Chin. Acta. \%: 609 doi: 1016/ 0009-8981(60) 90075-9. Pub.Med. (Cross Ref.).

Das, K., Tiwari, R. K. S., shrivastava, D. K. (2010). Techniques for evaluation of medicinal plants' products as antimicribial agent: current methods and future trends. Journal of Medicinal plants Research, 4 (2): 104-111.

Dasofunjo, K., Nwodo, O. F. C., Johnson, J.T., Ukpanukpong, R. U., Ugwu, M. N., and Ayo, U.I. (2013). Phytochemical screening and effect of ethanolic leaf extract of piliostigmathonningii on serum lipid profile of male albino rats. J. Nat. Prod. Plant Resour., 3 (2): 5-9.

Effiong, G. S., and Essien, G. E. (2017). Comparative effect of Nauclealatifolia leaf fractions on blood glucose and lipid profile parameters of alloxan-induced diabetic rats. Journal of Medicinal plants Research, 2(24): 387-392. 
Effiong, E. E., Igile, G. O., Mgbeje, B. I. A., Out, E.A., Ebong, P. E. (2013). Hepatoprotective and anti-diabetic effect of combined extracts of Moringaamygdalina in streptozotocininduced diabetic albino wistar rats. Journal of Diabetes and Endocrinology, 4(4): 45-50.

Friedwald, W. T., Levy, R.I and Fredrickson, D. S. (1970). Estimation of the concentration of low density lipoprotein cholesterol in plasma without use of the preparative ultracentrifuge. Clinical Chemistry, 18: 499-502.

Ghoraishian, S. M. (2006). The effect of Hazel leaf decoction on blood glucose reduction in the diabetic rats. World Journal of Medical Sciences, 1 (2): 144-146.

Law, M.R. (1999). Lowering heart disease risk with cholesterol reduction: evidence from observational studies and clinical trials. Eur. Heart J. Suppl. 1:S3-S8.

National Institute of Health, NIH. Consensus Statement, 5 (11): 1-23.

Ochalefu, D. O., Adoga, G. I., Luka, C.D., Abu, H.A., Amali, O.O.E., Agada, S.A., and Alonyenu, E. I (2018). Phytochemical composition and effects of Nauclealatifolia aqueous extracts on blood glucose levels of strptozotocin- induced diabetic wistar albino rats. Journal of Biomedical Research and Clinical Practice, 1(2): 157-163.

OECD. (2001). Test guidelines 425. Acute oral toxicity. Up- and- Down procedure

Okwori, A. E.J., Okeke, C. I., Uzoechina, A., Etukudoh, N.S., Amali, M. N., and Adetunji, J.A., (2008). The anti-diabetic potentials of Nauclealatifolia. African Journal of Biotechnology, 7(10): 13941399.

Omonkhelin, J. O., Silvanus, O. I., Ogochukwu, N. A., and Osaretin, A. I. (2014). Anti- diabetic and hypolipidaemic effects of methanol leaf extract of Napoleonavogelii (lecythidaceae). Hook and planch on alloxan-induced diabetes mellitus in rats. Tropical Journal of Pharmaceutical Research, 13 (11): 1903-1909.

Owolabi, O. J., Omogbai, E.K.I. (2011). Effects of Metformin on Potassium. Adapted and non- adapted diabetic patients. Trop. J. Pharm. Res., 11(5): 747-752.

Owolabi, O. J., Omogbai, E.K.I. (2013). Evaluation of the potassium channel activity. Levcromakalim (BRL 38227) on the lipid profile, electrolytes and blood glucose levels of streptozotocin-induced diabetic rats. J. Diabetics, 5: 88-94.

Pari, L., and Lartha, M. (2005). The Antidiabetic effect of Scopariadulus: Effect in lipid peroxidation in streptozotocininduced diabetes mellitus. General Physiology Biophysics, 24: 13-26.

Rang, H. P., Dale, M.M., Ritter, J. M., and Moore, P.K. (2003). Pharmacology $\left(5^{\text {th }}\right.$ Ed). Endinburgh: Churchhill Livingstone.

Rao, P.V., and Naibu, M.D. (2010). Antidiabetic effect of Rhinacanthusnasutus leaf extract in streptozotocin- induced diabetic rats. Libya Agricultural Research Centre, Journal International, 1: 310-312.

Rekha, N., Balaji, R., and Deecaraman, M. (2010). Anti-hyperglycaemic and antihyperlipidaemic effects of extracts of the pulp of Syzygiumcumini and the bark of Cinnmonzeylanicum in streptozotocininduced diabetic rats. Journal of Applied Biosciences 28: 1718-1730.

Thomson, M., Al-Arim, Z., Al-Quttan, K. K., Shaban, H. L., and Ali, M. (2007). Antidiabetic and hypolipidaemic properties of garlic (Allium sativum) in streptozotocininduced diabetic rats. Int. J. Diabetes and Metabolism, 15: 108-115 